\title{
Historia de las bibliotecas populares en la Argentina entre 1870 y 1955. Antecedentes bibliográficos
}

Doi: $10.25100 /$ hye.v14i51.6983

Artículo recibido: 05-01-2018 | Artículo aceptado: 10-05-2018

\section{Javier Planas}

Doctor en Ciencias Sociales por la Universidad Nacional de La Plata. Profesor de Bibliotecología en el Instituto de Investigaciones en Humanidades y Ciencias Sociales (Universidad Nacional de La Plata - Consejo Nacional de Investigaciones Científicas y Técnicas). Se ha ocupado de investigar temas vinculados con la historia de la lectura, el libro y las bibliotecas populares en Argentina.

Correo electrónico: planasjavier@yahoo.com.ar

Forma de citar este artículo: Planas, Javier. "Historia de las bibliotecas populares en la Argentina entre 1870 y 1955. Antecedentes bibliográficos". Historia y Espacio, vol. 14, n 51 (2018): 19-48. Doi: 10.25100/hye.v14i51.6983.

Artículo Tipo 2: de revisión. Este trabajo forma parte del proyecto de investigación del Programa de Incentivos del Ministerio de Educación de la Nación Argentina: Entramados de la cultura impresa en Buenos Aires: libros, lectores, bibliotecas (siglos XIX-XX)” (2017-2018). 
Historia de las bibliotecas populares en la Argentina entre 1870 y 1955. Antecedentes bibliográficos

Resumen: El artículo revisa la bibliografía disponible sobre las bibliotecas populares en la Argentina (1870 y 1955). A través de un análisis de los textos, se establece una periodización tentativa: por un lado, se destaca una fase genética (1870-1895), dentro de la cual se gestaron estos establecimientos y alcanzaron, con dificultades, ciertos niveles de aceptación social; por otro, se extiende una etapa de expansión y disputa (1895-1955), donde las bibliotecas populares se afirman definitivamente en el campo de las instituciones culturales del país. Entre las principales conclusiones, se indica que las investigaciones realizadas hasta la fecha no agotan la temática. Por último, y con base en los indicios disponibles, se establecen algunos principios de análisis que permitan auxiliar la tarea heurística de futuras indagaciones.

Palabras clave: Bibliotecas Populares, Políticas de Lectura, Lectores, Lectura, Sociabilidad.

\section{History of popular libraries in Argentina (1870-1955). Literature review}

Abstract: In this article the author presents a literature review on the evolution of popular libraries in Argentina organized in two time periods: i) the genesis phase (1870-1895), when these establishments were created and struggled to gain social acceptance, and ii) the expansion and dispute phase (1895-1955) when popular libraries succeed to become a consolidated cultural institution in the country. The author also presents principles of analysis to assist the heuristic labor of future inquiries.

Keywords: Popular libraries, Reading Policies, Readers, Reading; Sociability. 


\author{
Javier Planas
}

\title{
Historia de las bibliotecas populares en la Argentina entre 1870 y 1955. Antecedentes bibliográficos
}

\section{Introducción}

A mediados de la década de 1980 tuvo lugar una renovación historiográfica en las maneras de pensar y hacer la historia del libro que concentró diferentes debates y propuestas propedéuticas que, aún con distintos grados de consenso, tendieron a definir la disciplina en un nuevo arco metodológico y conceptual reconocido como historia de la lectura. Autores consagrados como Roger Chartier y Robert Darnton, entre otros que pudieran citarse, dieron origen a ese marco heurístico, que en líneas generales procura establecer cruces e hipótesis entre dos grandes series de elementos: de un lado, aquellos que conciernen a la actividad de los productores y los distribuidores de lo impreso, en sus respectivas búsquedas de convencimiento ideológico o estético, en la obtención de un lugar en el mercado de los bienes culturales o en el reconocimiento de sus pares; de otro, los identificados con las características de las comunidades de lectores y lectoras, cuyas trayectorias formativas, filiaciones sociales y expectativas variadas hicieron que los mensajes que circularon a través de los impresos adquirieran sentidos divergentes.

En Argentina, las resonancias de esas perspectivas se hicieron sentir a mediados de los noventa, cuando las obras de dichos autores comenzaron a circular de manera profusa ${ }^{1}$. Estas líneas de trabajo se ubicaron y dialogaron

1 Roger Chartier, El mundo como representación: estudios sobre historia cultural (Barcelona: Gedisa, 1992); Roger Chartier, Libros, lecturas y lectores en la Edad Moderna (Madrid: Alianza, 
con otras dos tradiciones interpretativas arraigadas en los campos literario e historiográfico: de un lado, la que corresponde a la recepción de los Estudios Culturales producida por los intelectuales cercanos a la revista Punto de vista en los años setenta, gestando con ella una mirada investigativa puesta en la circulación de los folletines y en la conformación de los públicos². De otro, la que se liga a los clásicos de la historia del libro argentina, cuya riqueza informativa y fuerza explicativa continúa vigente como material de consulta para quienes trabajan los siglos XVIII y XIX. ${ }^{3}$

En este nuevo contexto, perdieron potencia las antiguas maneras de entender la historia de las bibliotecas a través de los inventarios de sus colecciones, de las biografías de sus dirigentes o de las anécdotas fortuitas que las involucran a personajes más o menos célebres de la cultura. Investigaciones recientes como las de Alejandro Parada sobre los orígenes de la Biblioteca Pública de Buenos Aires en el inicio del siglo xix demuestran, a partir de los

1993); Roger Chartier, Sociedad y escritura en la Edad Moderna. La cultura como apropiación (México: Instituto Mora, 1995); Roger Chartier, Escribir las prácticas: Foucault, de Certeau Marin (Buenos Aires: Manantial, 1996); Roger Chartier, Escuchar a los muertos con los ojos. Lección inaugural en el Collège de France (Buenos Aires: Katz, 2008); Roger Chartier, Cardenio entre Cervantes y Shakespeare. Historia de una obra perdida (Buenos Aires: Gedisa, 2012); Roger Chartier y Guglielmo Cavallo (dirs.), Historia de la lectura en el mundo occidental (Buenos Aires: Taurus, 1997); Robert Darnton, La gran matanza de gatos y otros episodios de la cultura francesa (México: FCE, 1987); Robert Darnton, "Historia de la Lectura”. En: Formas de hacer historia, dirigido por Peter Burke (Madrid: Alianza, 1993), 177-208; Robert Darnton, Edición y subversión: literatura clandestina en el Antiguo Régimen (México: FCE, 2003); Robert Darnton, El negocio de la Ilustración. Historia editorial de la Encyclopédie, 1775-1800. (México: FCE, 2006); Robert Darnton, Los best sellers prohibidos en Francia antes de la Revolución. México: FCE, 2008); Robert Darnton, El beso de Lamourette: reflexiones sobre historia cultural (Buenos Aires: FCE, 2010)

2 Adolfo Prieto, Sociología del público lector (Buenos Aires: Leviatán, 1956); Adolfo Prieto, El discurso criollista en la formación de la Argentina moderna (Buenos Aires: Siglo XXI, 1988); Beatriz Sarlo, El imperio de los sentimientos. Narraciones de circulación periódica en la Argentina (1917-1927) (Buenos Aires: Catálogos, 1985); Beatriz Sarlo, "Raymond Williams y Richard Hoggart: sobre cultura y sociedad”. Punto de Vista, vol. 2, n. 6 (1979): 9-18.

3 Domingo Buonocore, Libreros, editores e impresores de Buenos Aires: esbozo para una historia del libro argentino (Buenos Aires: Bowker, 1974); Guillermo Furlong, Bibliotecas argentinas durante la dominación hispánica (Buenos Aires: Huarpes, 1944); María Ángeles Sabor Riera, Contribución al estudio histórico del desarrollo de los servicios bibliotecarios de la Argentina en el siglo XIX (Resistencia: Universidad Nacional del Nordeste, Dirección de Bibliotecas, 19741975); José Torre Revello, Orígenes de la imprenta en España y su desarrollo en América española (Buenos Aires: Institución Cultural Española, 1940). 
procesos fundacionales y de las primeras conducciones del establecimiento, las múltiples conexiones entre la vida cotidiana de este tipo de instituciones y los procesos de transformación más amplios de la cultura escrita ${ }^{4}$. Hasta 1870 las lógicas bibliotecarias que describió Parada no se modificaron sustancialmente, en buena medida porque el lectorado argentino se mantuvo durante largas décadas estructurado sobre una minoría ilustrada. Pero durante el último cuarto de siglo el crecimiento del público lector que supuso el ingreso de los sectores populares al campo de la lectura significó una trasformación radical de las concepciones y las prácticas bibliotecarias del país, hecho que se cristalizó con la emergencia de las bibliotecas populares. El contacto de costumbres y modos de hacer tan disímiles como los que suponen las raíces populares y la cultura culta que simbólica y materialmente encarna la biblioteca constituye un área fértil para el análisis. Pero aún con las contribuciones que se registraron en los últimos años, la materia es una deuda en la agenda de las ciencias sociales.

En lo que sigue, se propone una lectura crítica de los aportes medulares que hasta la fecha pueden deducirse de la bibliografía disponible, ordenados en el marco de una periodización generada con base en los procesos propiamente bibliotecarios. Al finalizar el trabajo se procura retener y sintetizar los principales puntos de análisis en un contexto interpretativo que facilite, con posterioridad, la formación de empresas heurísticas abocadas al estudio de las bibliotecas populares.

\section{Fase genética (1870-1895)}

Las bibliotecas populares en Argentina transitan un primer ciclo entre las décadas de 1870 y 1895 . El momento instituyente fue propiciado por la sanción de la Ley 419, que promovía la participación de las entidades de la sociedad civil en la organización de estas instituciones mediante la disposición de una subvención tangible en libros. Para administrar esta política, el Estado creó la Comisión Protectora de las Bibliotecas Populares, que además de distribuir los recursos se ocupó de atender las demandas técnicas de las bibliotecas, aspecto que cumplió de manera parcial mediante la publicación del Boletín

4 Alejandro E. Parada, Los orígenes de la Biblioteca Pública de Buenos Aires: antecedentes, prácticas, gestión y pensamiento bibliotecario durante la revolución de mayo (Buenos Aires: Instituto de Investigaciones Bibliotecológicas, Facultad de Filosofía y Letras, Universidad de Buenos Aires, 2009); Alejandro E. Parada, El Dédalo y su ovillo. Ensayos sobre la palpitante cultura impresa en la Argentina (Buenos Aires: Instituto de Investigaciones Bibliotecológicas, Facultad de Filosofía y Letras, Universidad de Buenos Aires, 2012). 
de las Bibliotecas Populares (1872/1875). Hasta 1875 el sistema funcionó con relativa normalidad y, en cierto sentido, superó las expectativas de los propios funcionarios, que en pocos años contabilizaron la fundación de un centenar de establecimientos a lo largo y ancho del territorio. Pero los efectos de la crisis económica internacional del período 1873-1876 que afectó al tesoro nacional, junto con la resolución política propuesta por el gobierno de Nicolás Avellaneda de achicar el gasto público, pusieron fin a la ley de bibliotecas y a los fondos destinados hasta entonces, en medio de una debacle coyuntural que se llevó empleos, sueldos, obras públicas, etc. De allí en más las asociaciones de lectores quedaron a su propia suerte. En los años que siguieron la mayoría de las bibliotecas cerraron sus puertas y, si bien cabe consignar que el Estado nacional no volvió a intervenir en esta área hasta 1908 con la restitución de la ley de protección, la línea de corte de esta fase genética puede radicarse a la mitad de la década de 1890 , cuando las agrupaciones y los partidos identificados con las izquierdas iniciaron una intensa actividad bibliotecaria ${ }^{5}$.

Los estudios dedicados al período inaugural son escasos, aunque leídos en conjunto brindan una idea global de los procesos históricos elementales que conciernen al tema. Una clasificación de estos antecedentes guiada por el recorte efectuado por los autores ofrece como resultado dos grupos distintivos: el primero y más nutrido está conformado por las indagaciones centradas en los textos bibliotecarios de Sarmiento; el segundo aborda cuestiones vinculadas con la evaluación de los resultados producidos por la implementación de la Ley 419 y la situación de las bibliotecas luego de su derogación.

La centralidad puesta en el análisis de los escritos de Sarmiento se explica por la envergadura de su personalidad y la gravitante participación que tuvo en esta historia, pues su producción sobre las bibliotecas informa de un plan de largo aliento, sustentado en un complejo entramado de temas en el que estas instituciones funcionan como una red que los conecta. Entre esos elementos se pueden citar: la planificación y la organización de políticas editoriales, la enunciación de propuestas de lecturas, la expresión de proposiciones filosóficas, éticas y morales, la sanción de leyes y de reglamentos, la formación de oficinas especializadas y la concreción de espacios de sociabilidad letrada, entre otros. Las intervenciones que ordenan estos tópicos tuvieron lugar entre las décadas de 1840 y 1880 en distintas revistas y periódicos, y fueron reunidas por Juan Pablo Echagüe y editadas por la Comisión Protectora en 1939 bajo el título

5 Javier Planas, Libros, lectores y sociabilidades de lectura. Una historia de los orígenes de las bibliotecas populares en Argentina (Buenos Aires: Ampersand, 2017). 
de Páginas Selectas de Sarmiento sobre Bibliotecas Populares - la compilación, sin embargo, no es exhaustiva $-{ }^{6}$. La prolífica tarea de difusión bibliotecaria desarrollada por el autor tenía un objetivo claro: contribuir con la formación de un público amplio de lectores y, de modo general, con la modernización cultural de la sociedad civil que el poder político alentó desde 1860, entre cuyas medidas principales se ubicó la estimulación de la inmigración europea y la estructuración del sistema educativo. Estas conclusiones se extraen del análisis que María Ángeles Sabor Riera hizo en Contribución al estudio histórico del desarrollo de los servicios bibliotecarios de la Argentina en el siglo XIX7. Este trabajo puede considerarse clave, en tanto que fue el primero que sistematizó el ideario sarmientino con rigor crítico, tras varias décadas de olvidos, reseñas aisladas y escritos sencillamente apologéticos, entre cuyas referencias cabría identificar las reminiscencias que Leopoldo Lugones dejó en Historia de Sarmiento, o las reflexiones que el propio Echagüe publicó sobre el asunto en Libros y bibliotecas ${ }^{8}$. El aporte de Sabor Riera, sin embargo, no se adentra en el producto sociocultural que dejó la Ley 419 implementada por el gobierno de Sarmiento y, de esa manera, la cuestión bibliotecaria quedó reducida al examen de un conjunto orgánico de textos.

Desde un ángulo diferente, resulta indispensable el capítulo que Bernardo Subercaseaux le dedicó al tema en Historia del libro en Chile ${ }^{9}$. El ensayo aborda la noción sarmientina de libro como entidad dual, esto es: como fase material, referida al objeto que se produce y se comercializa, y como instancia simbólica, donde el valor relativo se precisa en términos socioculturales. Este doble carácter se percibe con exactitud en los proyectos editoriales diagramados por el autor ${ }^{10}$, donde imaginó la multiplicación de las bibliotecas como ámbitos de recepción y circulación de la oferta literaria entre el público popular, cuya existencia durante muchos años tuvo más consistencia en sus apelación

6 Comisión Protectora de Bibliotecas Populares, Paginas selectas de Sarmiento sobre bibliotecas populares (Buenos Aires: la Comisión, 1940).

7 María Ángeles Sabor Riera, “Contribución al estudio histórico”, 1974-1975.

8 Leopoldo Lugones, Historia de Sarmiento (Buenos Aires: Otero \& Compañía, 1911); Juan Pablo Echagüe, Libros y bibliotecas (Buenos Aires: Comisión Protectora de Bibliotecas Populares, 1939).

9 Bernardo Subercaseaux, Historia del libro en Chile (alma y cuerpo), (Santiago de Chile: LOM, 2000).

10 Javier Planas, "Para un catálogo atractivo: libros y política editoriales para las bibliotecas populares. La propuesta de Domingo Faustino Sarmiento". Información, Cultura y Sociedad, $n^{\circ} 20$ (2009): 63-81. 
discursiva que en la realidad fáctica ${ }^{11}$. No obstante, esas intervenciones se transformaron con el paso de los años en un verdadero discurso sobre la libertad de lectura, cuya eficacia fue puesta en juego con distinta suerte en la construcción de los criterios de creación de las colecciones. En Chile, por ejemplo, las disputas por la formación sentimental de los ciudadanos que sostuvo frente a las posiciones ultraconservadoras de la Iglesia Católica no tuvieron los efectos deseados sobre las bibliotecas populares que allí contribuyó a organizar ${ }^{12}$. Pero esta experiencia fue capitalizada en su regreso a la Argentina, donde logró imponer durante su presidencia una legislación que aseguraba la elección de las obras en manos de los lectores ${ }^{13}$. La densidad cultural de esta realización fue iluminada por Graciela Batticuore al analizar las opiniones que enfrentaron a Sarmiento con Vicente Quesada a propósito del devenir de la Biblioteca Pública de Buenos Aires en los años previos a su nacionalización ${ }^{14}$. Este conflicto reveló dos maneras diferentes de enfocar las políticas públicas de acceso al libro: una preocupada por ampliar la difusión y otra apegada a los circuitos letrados tradicionales. En estos cruces también se percibe la modernidad del proyecto bibliotecario sarmientino, cuya insistencia en el préstamo domiciliario de las obras como metodología de apertura transformó el campo bibliotecológico nacional, todavía adherido a las ideas de conservación $\mathrm{y}$ difusión selecta ${ }^{15}$.

11 Adolfo Prieto. "Sarmiento: casting the readers, 1839-1845". En: Sarmiento: author of a nation, Tulio Halperin Donghi et. Ál. Berkeley: University of California Press, 1994, 256-271.

12 Graciela Batticuore, La mujer romántica:lectoras, autoras y escritores en la Argentina: 1830-1870 (Buenos Aires: Edhasa, 2005). Juan Poblete, Literatura chilena del siglo XIX: entre públicos lectores y figuras autoriales (Santiago: Cuarto Propio, 2003); Bernardo Subercaseaux, "Historia del libro en Chile", 2000.

13 Javier Planas, “«Cuáles serán los libros buenos?» Tensiones culturales y políticas de lectura en los orígenes de las bibliotecas populares en Argentina”, ponencia presentada en el II Coloquio Argentino de Estudios sobre el Libro y la Edición (Córdoba, 2016).

${ }^{14}$ Graciela Batticuore, “Libros, Bibliotecas y lectores en las encrucijadas del progreso”. En: Historia Crítica de la Literatura Argentina: el brote de los géneros, dirigido por Alejandra Laera. 413-440. Buenos Aires: EMECÉ, 2010.

15 Javier Planas, "Hacer las reglas del hacer: concepciones y rutinas en los reglamentos de las bibliotecas populares en la Argentina (1870-1875)". Revista de Historia Regional, 19, n. ${ }^{\circ} 1$ (2014a): 203-226. http://www.revistas2.uepg.br/index.php/rhr/article/viewFile/6117/4095 Javier Planas, "La esencia de una biblioteca popular. Una polémica sobre los lectores y las modalidades de acceso a la lectura”, ponencia presentada en las Segundas Jornadas de Intercambio y Reflexión acerca de la Investigación Bibliotecología. La Plata, 2011, http://jornadabibliotecologia.fahce.unlp.edu.ar/jornadas2011/actas-2011/planas-la-esencia 
Hasta hace poco tiempo apenas se tenían noticias sobre los resultados producidos por la política bibliotecaria de la década de 1870. Alo largo de todo el siglo xx apenas se cuentan tres trabajos. El primero es de Amador Lucero: Nuestras bibliotecas desde $1810^{16}$. La investigación debe leerse como un balance de época, pero también a la luz de la restitución de la protección a las bibliotecas populares por parte del Estado nacional en 1908. En el capítulo dedicado al tema, el autor se empeñó en alertar a los flamantes funcionarios sobre los errores del pasado, pero relegó el carácter crítico que la cuestión merecía. Su tesis toma como punto de partida la crisis que padecieron las bibliotecas en 1876, tras la supresión de las subvenciones. Su pregunta central — de verdadero valor heurístico-buscó comprender por qué esas instituciones no lograron sobreponerse por sí mismas. Pero las respuestas que ofreció se concentraron en una sola variable: el desempeño de la Comisión Protectora, a la que le adjudicó falta de pericia para desarrollar el programa y falencias en el asesoramiento de los lectores. Si por momentos el trabajo de Lucero deja muchas dudas sobre su rigor interpretativo, la tarea de archivo tiene el mérito de salirse de la absorbente figura de Sarmiento - a quien, por otra parte, le dedicó algunas páginas-. A veinte años de esta publicación aparece Historia del libro y de las bibliotecas en la Argentina, de Nicanor Sarmiento ${ }^{17}$. Dentro del contexto panorámico de la obra, el autor retoma algunas problemáticas vinculadas con el declive de las bibliotecas, pero a diferencia de Lucero, sus explicaciones remiten a factores de tipo coyuntural: la obvia derogación de la Ley 419, los continuos cambios producidos en el sistema de instrucción pública y las condiciones políticas y económicas. Mucho tiempo después, Nicolás Tripaldi volvió sobre esta historia pero lo hizo con fines metodológicos, esto es, retomó el derrotero de las bibliotecas populares durante el final del XIX e identificó con base en esta experiencia algunas variables que sirvieran para evaluar las crisis bibliotecarias venideras. En este contexto, sugirió que el marco macrobibliotecológico, la sociología de lectores, la cooperación bibliotecaria y la formación profesional constituían elementos indispensables para analizar las coyunturas críticas ${ }^{18}$. En un sentido global, el trabajo contribuye a la discusión sobre la constitución

\footnotetext{
${ }^{16}$ Amador Lucero, Nuestras bibliotecas desde 1810 (Buenos Aires: Coni, 1910).

${ }^{17}$ Nicanor Sarmiento, Historia del libroy de las bibliotecas en la Argentina (Buenos Aires: Imprenta Luis Veggia, 1930).

18 Nicolás Tripaldi, "Indicadores de crisis: el caso de las bibliotecas populares argentinas", ponencia presentada en la XXV Reunión Nacional de Bibliotecarios: la biblioteca y los bibliotecarios en tiempos de crisis (Buenos Aires, 1991).
} 
del objeto de estudio, pero dados los objetivos fijados por el autor, la cuestión historiográfica quedó en un segundo plano.

Durante los últimos años aparecieron una serie de estudios que, de distintas maneras, enfatizaron la cuestión sociocultural de las bibliotecas populares. A partir de estos aportes se sabe que durante el periodo se inauguró una política que articuló de forma compleja el poder estructurante del Estado y la potencia creativa de la sociedad civil ${ }^{19}$. Esa conjunción supuso, de un lado, el montaje de una burocracia y la elaboración de un saber especializado sobre bibliotecas lo suficientemente didáctico como para servir de asesoramiento a los lectores interesados. Por otro, los asociados debieron desplegar una serie de tácticas y operaciones que no solo tendieron a obtener los beneficios estatales, sino también a ordenar un lugar y construir un espacio para la lectura ${ }^{20}$. Con este objeto pusieron en acto los resortes asociacionistas típicos de los sectores mesocráticos, tanto en lo que respecta a la formación política y democrática de los establecimientos, como a los propiamente bibliotecarios: elección de lecturas, confección de los reglamentos, organización de los catálogos, celebración de veladas literarias, etc. Muchas de las objetivaciones en términos de prácticas que tuvieron lugar durante ese período permanecieron en el largo de los años, aunque fueron resignificadas de distintas maneras. Los trabajos de Marcela Vignoli y Alberto Tasso sobre la Sociedad Sarmiento de Tucumán y su homónima de Santiago del Estero, respectivamente, aportan elementos sobre los sentidos y las funciones que la llamada generación del ochenta les atribuyó a las bibliotecas como entidades reguladoras de la lectura pública entre las postrimerías del siglo XIX y los primeros años del XX, sin duda en sintonía con los diagnósticos poco promisorios sobre el campo de la lectura popular que prevalecía entre ellos ${ }^{21}$. Una de las razones de esta suerte de giro conservador

19 Javier Planas, “Las bibliotecas populares en la Argentina entre 1870 y 1875 . La construcción de una política bibliotecaria”. Informatio, 18, n. ${ }^{\circ} 1$, (2014b): 66-88 http://informatio.eubca. edu.uy/ojs/index.php/Infor/article/view/152/229

20 Javier Planas, "Lugares y espacios para la literatura en la Argentina del xıx. Las bibliotecas populares en los circuitos de la lectura" en Tropos, tópicos y cartografías: figuras del espacio en la literatura latinoamericana, editado por Carolina Sancholuz y Valeria Añón, (La Plata: Facultad de Humanidades y Ciencias de La Educación, 2017). www.libros.fahce.unlp.edu. ar/index.php/libros/catalog/view/89/110/810-1

${ }^{21}$ Alberto Tasso. "La biblioteca Sarmiento de Santiago del Estero (1880-1915). Socorros mutuos, libros y lectores”. Políticas de la Memoria, n.․ㅡ 14 (2013): 105-109.; Marcela Vignoli. "Asociacionismo, cultura y política en tiempos de crisis, la Sociedad Sarmiento de Tucumán, 1900-1909”. Travesías, n 12 (2010): 187-214 http://www.travesia-unt.org.ar/pdf/trave- 
—o proceso de sacralización de la autoridad conferida a los textos- hay que buscarla en el arribo de los maestros normalistas y los egresados de los colegios nacionales, cuya confianza en la disciplina y los métodos se extendió por fuera del aula y alcanzó a muchas bibliotecas populares ${ }^{22}$. La situación de las lectoras expresa una de las caras de este cambio: mientras que a comienzo de la década de 1870 la Comisión Protectora alentaba desde el Boletín la participación de las mujeres en las veladas literarias y en las juntas directivas, durante las décadas de 1880 y 1890 los discursos que circularon por las revistas de educación reclamaron de manera sistemática por la tutela masculina en la administración de las obras ${ }^{23}$.

\section{Etapa de expansión y disputa (1890-1955)}

El período 1890-1955 ha suscitado mayor interés para los investigadores. En este contexto, las bibliotecas populares se multiplicaron de manera paralela al desarrollo de tres de fenómenos sociales gravitantes para la historia cultural argentina del siglo xx: por una parte, la consolidación del cauce inmigratorio, la expansión urbana y la constitución de nuevas solidaridades barriales; por otra, la cristalización de la clase obrera y la emergencia de los partidos políticos de izquierda; finalmente, el afianzamiento definitivo de la cultura impresa, tangible en el despegue de las tasas de alfabetización, la modernización del mercado editorial y la diversificación de la producción bibliográfica y del público lector, entre otros aspectos. En el marco de esta coyuntura, las bibliotecas populares fueron objeto de aproximaciones que analizaron la influencia de estas instituciones en las áreas metropolitanas y periféricas a través de la descripción

sia12_8.pdf; Marcela Vignoli. "Educadoras, lectoras y socias. La irrupción de las mujeres en un espacio de sociabilidad masculino. La Sociedad Sarmiento de Tucumán (Argentina) entre 1882 y 1902". Secuencia, n 80, (2011): 43-62; Marcela Vignoli, Sociabilidad y cultura política. La sociedad Sarmiento de Tucumán (1880-1914). (Rosario: Prohistoria, 2015).

${ }^{22}$ Adriana De Miguel et. ál. "Normalismo, cultura letrada y resistencia de la oralidad en la historia de la lectura y la escritura en Argentina”. Ciencia, docencia y tecnología, n 34 (2007): 97-127; Adriana De Miguel. "Escenas de lectura escolar. La intervención normalista en la formación de la cultura letrada moderna”. En Historia de la lectura en la Argentina. Del catecismo colonial a los netbooks estatales. Héctor Rubén Cucuzza y Roberta Paula Spregelburd. Buenos Aires: Editores del Calderón, 2012. 133-169.

23 Javier Planas, “Lectoras, autoras y bibliotecarias: presencias y ausencias de las mujeres en las bibliotecas populares de la Argentina (1870-1890)”, ponencia presentada en las Terceras Jornadas de Intercambio y Reflexión acerca de la Investigación Bibliotecología (La Plata, 2013). http://jornadabibliotecologia.fahce.unlp.edu.ar/jornadas-2013/actas-2013/planas.pdf/view 
de su estructura organizativa, la composición social y política de sus dirigentes y lectores, así como también el tipo de lecturas y las actividades culturales que promovieron. En esta periodización es posible advertir dos momentos: uno de gestación, que se inicia en 1890 y finaliza terciada la década de 1910; otro de expansión, que abarca los años comprendidos entre el cierre de la Primera Guerra Mundial y el Golpe de Estado de 1955. Con independencia de este criterio analítico de distinción, que prioriza el abordaje del tema según las características de los procesos históricos propiamente bibliotecarios y de la bibliografía, cabe consignar que la mayoría de los trabajos que exploraron este fenómeno lo hicieron como parte de objetos de estudios de mayor tradición historiográfica. En este sentido, es posible identificar una diferencia elemental en los abordajes: de un lado, se ubica la bibliografía que privilegió los diversos encastres de la cultura impresa en las zonas de lo culto y lo popular - en sus mutuas relaciones y dependencias, pero también bajo una pluralidad de definiciones y alcances - . De otro, se encuentra el conjunto de investigaciones que concedió preferencia a los procesos de circulación y mediación de la prolífica y heterogénea producción de literatura socialista y anarquista en la constitución de la cultura política de los obreros. Las discrepancias teóricas y retóricas en el sujeto de interpelación pueden remontarse a la vieja querella sobre los usos de las categorías "cultura popular" y "cultura obrera" ${ }^{24}$. No obstante, al recortar el objeto de conocimiento sobre la noción de biblioteca como espacio material de lectura, el conjunto de instituciones emergentes durante esta etapa histórica no solo compartieron en gran medida el mismo público, sino también la convicción de que el impreso tenía un lugar preponderante en la vida de las personas, ya sea como instrumento de progreso, herramienta de liberación, dispositivo de nacionalización o, sencillamente, como alternativa a la educación de la calle y los crecientes mensajes de la cultura de masas. Quienes se ocuparon de fomentar las bibliotecas y generar discursos sobre la lectura compartieron, aun en sus diferencias, la convicción según la cual era necesario acompañar a los lectores y las lectoras. Solo la matriz de sentidos sarmientina oriunda del xix los condujo a aceptar a regañadientes aquello que consideraban mala literatura, a la espera de un futuro más promisorio para el campo de la lectura.

El estadio de gestación coincide con la formación de las denominadas bibliotecas obreras, que inicialmente funcionaron con pequeñas colecciones

${ }^{24}$ Luca Poy. "Socialismo y anarquismo en la formación de la clase obrera en Argentina: problemas historiográficos y apuntes metodológicos". Archivos de historia del movimiento obrero y la izquierda, $\mathrm{n}^{\circ}$ 1, (2012): 13-34. 
de libros que circulaban de mano en mano entre los allegados a los partidos o las asociaciones afines a los intereses del proletariado. En este sentido, puede considerarse como precedente el Club Vorwärts, que al promediar la década de 1880 disponía de algunas obras para sus miembros ${ }^{25}$. Pero las bibliotecas, en su forma institucional, no aparecen sino hasta 1897, cuando los socialistas organizaron la Biblioteca Obrera tras la disolución del Centro Socialista de Estudios ${ }^{26}$. La bibliografía disponible es coincidente respecto del lugar preponderante que a partir de este momento adquiere la vertiente socialista en la tradición bibliotecaria nacional. En primer lugar, porque fueron quienes propiciaron una mayor apertura comunitaria mediante la modificación de los estatutos, la ampliación de los criterios de selección del material de lectura y la implementación de técnicas bibliotecológicas modernas. En segundo orden, porque su estructura de difusión favoreció el crecimiento cuantitativo de las bibliotecas a nivel nacional, hasta llegar a la notable cifra de 397 instituciones para el año $1932^{27}$. No obstante, es necesario subrayar que durante su período constitutivo estas bibliotecas se mantuvieron como espacios cuasi cerrados. Nicolás Tripaldi y Eugenia Sik coinciden en señalar que este escenario comenzó a cambiar en 1908, a partir de la renovada intervención estatal que supuso la restitución de la protección a las bibliotecas tras treinta y dos años de ausencia, en una estrategia que sin duda debe leerse como reacción conservadora a la proliferación de los espacios de lectura elaborados bajo la influencia de las izquierdas ${ }^{28}$. La fiscalización gubernamental que, a priori,

${ }^{25}$ Horacio Tarcus, Marx en la Argentina. Sus primeros lectores obreros, intelectuales y científicos (Buenos Aires: Siglo XXI, 2007).

${ }^{26}$ Dora Barrancos, Educación, cultura y trabajadores (1890-1930) (Buenos Aires: Centro Editor de América Latina, 1991); María Ángeles Sabor Riera, Contribución al estudio histórico del desarrollo de los servicios bibliotecarios de la Argentina en el siglo XIX (Resistencia: Universidad Nacional del Nordeste, Dirección de Bibliotecas, 1974-1975); Nicolás Tripaldi. “La política y los centros de lectura: los socialistas fundan sus primeras bibliotecas en la ciudad de Buenos Aires 1894-1899”. Revista de Biblioteconomía de Brasilia, 20, nº 1 (1996): 41-51; Nicolás Tripaldi. "Origen e inserción de las bibliotecas obreras en el entorno bibliotecario argentino: fines del siglo XIX y primer tercio del siglo XX”. Libraria: Correo de las Bibliotecas, $1, \mathrm{n}^{\circ} 1$ (1997): 22-37.

27 Emilio Corbiére, "La cultura Obrera Argentina como base de transformación social (18901940)", Herramienta: debate y crítica marxista, n. 12 (2000)

${ }^{28}$ Eugenia Sik, "Ángel M. Giménez, "bibliotecarios”. Apunte para una historia de las "bibliotecas obreras" en Argentina”, ponencia presentada en el II Coloquio Argentino de Estudios sobre el Libro y la Edición (Córdoba, 2016); Tripaldi, “Origen e inserción”, 22-37. 
significaba esta medida, no se tradujo en un rechazo directo por parte de los fomentadores. La posibilidad de acceder al subsidio puso en una encrucijada a las bibliotecas obreras, que en adelante debieron decidir entre integrarse o no a la normalización pretendida por la conducción de la Comisión Protectora. Los anarquistas quedaron al margen del sistema, en parte porque fueron objeto del aparato represivo estatal - al punto que, según varios especialistas, el declive del movimiento puede registrarse entre 1910 y 1915 - y otro tanto debido a la baja organicidad de su estructura funcional - aspectos que, sin duda, estaban sustentados por el conjunto de convicciones que los reunió-. Los socialistas, en cambio, optaron por sumarse a la posición legalista y usufructuar los beneficios de la legislación. La convivencia que se abrió desde entonces entre el gobierno y los simpatizantes del partido no estuvo exenta de conflictos, verificables tanto en las formaciones discursivas como en los procedimientos comprometidos con la obtención de las subvenciones ofrecidas por el tesoro nacional. Pero más allá de estas tensiones y de los resultados que dejó en cada caso, con el correr de los años la vertiente socialista contribuyó de forma decisiva a darle vigor a la incipiente tradición bibliotecaria de la Argentina, aspecto que puede comprobarse en la intensa participación que tuvieron en el campo durante el período posterior.

Antes de proseguir, resulta necesario detenerse un instante en las relaciones entre los anarquistas y la organización de las bibliotecas. A decir verdad, la temática apenas fue explorada. La mayoría de las referencias disponibles se encuentran en estudios globales como los de Juan Suriano ${ }^{29}$, donde las menciones al asunto están sumergidas en el análisis del dispositivo cultural y político desplegado por el anarquismo. Es razonable pensar que, como señaló recientemente Mariana Di Stefano ${ }^{30}$, las dificultades que encontraron estos grupos para sostener locales estables hayan conspirado con la lógica que exige la biblioteca, aspecto que no obstaculizó, sin embargo, su radicación como instancias menos fijas y estables de lo que pueden sugerir las representaciones arquetípicas del imaginario social para estas instituciones. Entre las primeras aproximaciones de una investigación en curso, Sik abordó la problemática bibliotecaria de manera específica a través de un relevamiento de testimonios aparecidos en distintos periódicos libertarios entre 1898 y 1905 —período

29 Juan Suriano, Anarquistas: cultura política y libertaria, 1890-1910 (Buenos Aires: Manantial, 2008).

${ }_{30}$ Mariana Di Stefano, El lector libertario: prácticas e ideologías del anarquismo argentino (18981915) (Buenos Aires: Eudeba, 2013). 
que se considera, en consonancia con la tesis de Suriano, la época de apogeo del anarquismo- ${ }^{31}$. Las conclusiones del trabajo no solo corroboran en líneas generales la sostenida voluntad de muchos militantes por la creación y el mantenimiento de las bibliotecas como espacios de formación, sino que además agrega como novedad la detección de un incipiente discurso que, si bien no contó con obras monográficas al estilo de la que publicó el socialista Ángel Giménez ${ }^{32}$, talló un matiz polémico dentro del campo bibliotecario de la época.

El momento de expansión de las bibliotecas populares que tuvo lugar terciada la segunda década del siglo xx no solo se nutrió de la militancia de izquierda y la renovada acción del Estado, sino que además se enriqueció con la corriente de participación vecinal generada con el fomentismo y la emergencia de entidades vinculadas a otros partidos políticos y a la Iglesia Católica ${ }^{33}$. Estos temas han ocupado la mayor cantidad de indagaciones en el área y, con más o menos intensidad, todas ellas son deudoras de los trabajos que Leandro Gutiérrez y Luis Alberto Romero publicaron sobre los vínculos entre la cultura y la política en la conformación de las identidades de los sectores populares en Buenos Aires en el período de entreguerras ${ }^{34}$. En este sentido, es importante destacar que el análisis de las sociedades barriales y de las bibliotecas populares

${ }^{31}$ Eugenia Sik, "La creación de bibliotecas durante el apogeo del anarquismo argentino (18981905)”, Ponencia presentada en el I Congreso Internacional de Investigadorxs sobre Anarquismo (Buenos Aires, 2016).

32 Ángel M. Giménez, Nuestras Bibliotecas Obreras, (Buenos Aires: La Vanguardia, 1932).

${ }^{33}$ Sandra Carli. "Infancia y sociedad: la mediación de las asociaciones, centros y sociedades populares de educación”. En Sociedad Civil y Estado en los orígenes del sistema educativa argentino, dirigida por Adriana Puiggros. 13-46. Buenos Aires: Galerno, 1991.; Ángel M. González. "Lo propio y lo ajeno: Actividades culturales y fomentismo en una asociación vecinal, Barrio Nazca (1925-1930)”. En Mundo urbano y cultura popular. Estudios de Historia Social Argentina, compilada por Diego Armus. 91-128 (Buenos Aires: Sudamericana, 1990) ; Luis Alberto Romero, "El Estado y las Corporaciones". En De las cofradías a las organizaciones de la sociedad civil: historia de la iniciativa asociativa en la argentina (1776-1990), Roberto di Stefano et. Ál. 169-275 (Buenos Aires: Edibal, 2002); Joel Horowitz, "Finding a Place to Read: Popular Libraries in Greater Buenos Aires before 1945”, ponencia presentada en el Seminario de discusión del Programa de Estudios sobre Saberes de Estado y Elites Estatales, (Buenos Aires, 2016); Perrot-Desseaux. «Les bibliothèques populaires argentines, ou quand la promotion de la lecture est prise en charge par la "communauté"». En: Des bibliothèques populaires à la lecture publique, dirigido por d'Agnès Sandras. 373-394. Villeurbanne: Presses de l’Enssib, 2014.

${ }^{34}$ Leandro Gutiérrez y Luis Alberto Romero, Sectores populares, cultura y política: Buenos Aires en la entreguerra (Buenos Aires: Sudamericana, 1995). 
que proponen los autores forma parte de un dispositivo metodológico que intenta asir esas identidades mediante la captación de las prácticas sociales en diferentes ámbitos de producción. De manera que la noción de "sectores populares" no remite a un sujeto histórico constituido, sino más bien a un área social y a unos espacios definidos donde las personas procesaron de modo colectivo sus experiencias. De allí que, entre otras vías de análisis, Gutiérrez y Romero hayan apelado al estudio de las instituciones barriales como ámbitos de formación. En este contexto, las bibliotecas populares conformaron lugares específicos donde, al decir de los autores, se produjo un cruce singular entre algunos elementos de la alta cultura (o cultura culta) y las vivencias de los habitantes de los barrios porteños periféricos.

Sibien se sabe que los militantes socialistas fueron quienes se destacaron por su prolífica tarea bibliotecaria - que desarrollaron junto con la organización de escuelas y asociaciones de recreos infantiles como instancias diferenciadas de un mismo dispositivo pedagógico — ${ }^{35}$, los estudios disponibles no se focalizaron en la injerencia directa del partido, sino en la influencia que esos cuadros tuvieron en la sociabilidad de estas instituciones. Esta participación, que sin duda segó los destinos y las misiones de estas entidades, fue analizada bajo tres instancias: por una parte, el recorte cultural operado por quienes estuvieron a la cabeza de las organizaciones, en general a cargo de la formación de las colecciones. Por otra - y cuando las fuentes así lo permitieron-, la recepción de esos contenidos por parte del público, en relación con las expectativas y los intereses generados por la propuesta asociativa. Finalmente, las prácticas que tuvieron lugar en esos ámbitos, principalmente mediante el examen de las veladas literarias, las conferencias y las festividades, pero también a través de los diálogos y las disputas en el seno de las asambleas de rigor. De manera global, las conclusiones apuntan a señalar que los lectores y las lectoras que transitaron por estos establecimientos concibieron al libro y a la lectura como claves simbólicas de un renovado estatuto de valores y expectativas ligados, en general, a las aspiraciones de progreso social. Asimismo, se destaca la diferencia de actitudes y prácticas entre los denominados difusores de la lectura,

35 Barrancos Dora, Educación, cultura y trabajadores (1890-1930) (Buenos Aires: Centro Editor de América Latina, 1991); Dora Barrancos. "Socialistas y la suplementación de la escuela pública: la Asociación de Bibliotecas y Recreos infantiles (1913-1930)”. En Mujeres en la Educación. Género y docencia en la Argentina: 1870-1930, editado por Graciela Morgade. 130-150 (Buenos Aires: Miño Dávila, 1997); Nicolás Tripaldi. “Las mujeres de la política, los niños de la calle y las bibliotecas: apostillas bibliotecológicas sobre el tema de la Asociación de Bibliotecas y Recreos Infantiles". Información, Cultura y Sociedad, n. 7 (2002): 81-101. 
comprometidos con las actividades cotidianas de los establecimientos, y el público, caracterizado por su intermitencia, tanto en la vocación participativa como en los gestos de apropiación cultural - la hipótesis sobre la atención oblicua o discontinua de los lectores que Richard Hoggart elaboró sobre las modalidades de la lectura de la clase obrera inglesa se percibe subrepticiamente en este conjunto de investigaciones, aunque cabe consignar que hasta el momento solo se han aportado indicios-.

Si el Partido Socialista construyó una estrategia más flexible de captación de público, el Partido Comunista (PC) se mantuvo mucho más rígido en la oposición "biblioteca popular" "biblioteca obrera”. A este respecto, Hernán Camarero brindó detalles de la acción del partido frente a la cuestión bibliotecaria - en el marco de un estudio global sobre los comunistas y el mundo del trabajo en la Argentina entre 1920 y $1935-{ }^{36}$. Allí se puede constatar la insistencia inicial de este grupo por mantenerse al margen de lo que consideraban la cultura burguesa a la que contribuían a difundir las bibliotecas populares. En contrapartida, las bibliotecas del PC circunscribían su oferta literaria a un selecto grupo de lecturas vinculada con la cultura marxista y, en menor proporción, con las novelas de tintes sociales típicas del finales del XIx. Esta posición no se mantuvo siempre estable. Camarero reconoce algunos desplazamientos que oscilaron entre miradas apegadas a la tradición marxista-leninista, hacia propuestas más abiertas, que implicaron cambios de perspectivas políticas e historiográficas al incorporar, por ejemplo, ciertas reivindicaciones de la Revolución de Mayo y la tradición liberal, antes combatida. Por último, el autor destaca que, con el golpe de Estado de 1930 y la persecución del partido, las bibliotecas se vieron forzadas a pasar por un período a la clandestinidad, del que comenzaron a recuperarse de manera progresiva dos años después — en coincidencia con todas las actividades de la organización-.

Sobre los pasos dados por Gutiérrez y Romero, aparecieron de forma progresiva investigaciones que aportaron conocimiento sobre las bibliotecas populares fuera de los límites de Buenos Aires, más exactamente en las

36 Hernán Camarero, A la conquista de la clase obrera: los comunistas y el mundo del trabajo en la Argentina, 1920-1935 (Buenos Aires: Siglo XXI, 2007). 
ciudades de Tandil ${ }^{37}$, Mar del Plata ${ }^{38}$, Rosario ${ }^{39}$ y La Plata ${ }^{40}$. Los estudios de Ricardo Pasolini y Nicolás Quiroga agregan, a lo ya conocido, un análisis de la circulación de los libros a través de los registros de préstamos, entre cuyos resultados se destaca la corroboración de una verdadera vocación lectora, con una clara inclinación hacia la lectura de novelas. Esta comprobación - así como la que Joel Horowitz estableció de forma reciente para las bibliotecas porteñas del mismo período-, ponen en discusión una de las conclusiones de Gutiérrez y Romero sobre los usos de estas bibliotecas, según la cual los sectores populares las utilizaron escasamente como espacios de provisión de material de lectura y, en cambio, se refugiaron en ellas como instancias de legitimación cultural. Desde el punto de vista cuantitativo, las cifras de préstamo restituidas por Pasolini y Quiroga, respectivamente, no resultan nada desdeñables, aun aceptando la distancia entre un libro llevado a domicilio y su lectura efectiva. Por lo demás, ningún trabajo presenta esas estadísticas relacionadas de forma sincrónica con las que pudieran ofrecer bibliotecas de otros países - de manera tal que, por el momento, solo se puede deducir con cierto esfuerzo un estándar nacional-. Cualitativamente, los análisis elaborados hasta la fecha no avanzaron lo suficiente en lo que respecta al conocimiento de las prácticas de apropiación de estos lectores, de manera que muchas de las conclusiones deben considerarse en su carácter provisional.

Por su parte, Diego Roldán volvió sobre la cuestión de las bibliotecas populares para revisar, en la sociedad rosarina de entreguerras, los vínculos entre los crecientes mensajes producidos por la progresiva expansión de la industria cultural y las estrategias que siguieron las bibliotecas para recortar y

${ }^{37}$ Ricardo Pasolini, "Entre la evasión y el humanismo. Lecturas, lectores y cultura de los sectores populares: La Biblioteca Juan B. Justo de Tandil, 1928-1945”. Anuario IEHS, n. ${ }^{\circ} 12$ (1997): 373-401.

38 Milagros Dolabani, "La Biblioteca Popular Juventud Moderna: teatro, política, sociabilidad y esparcimiento (1939-1947)", ponencia presentada en el I Congreso Internacional de Investigadorxs sobre Anarquismo (Buenos Aires, 2016); Nicolás Quiroga. "Lectura y política. Los lectores de la biblioteca popular juventud moderada de Mar del Plata (fines de los años treinta y principio de los cuarenta)". Anuario IEHS, n. ${ }^{\circ} 18$ (2003): 449-474.

39 Diego Roldán, La invención de las masas: Ciudad, corporalidades y culturas. Rosario, 1910-1945 (La Plata: Universidad Nacional de La Plata. Facultad de Humanidades y Ciencias de la Educación, 2015) http://www.libros.fahce.unlp.edu.ar/index.php/libros/catalog/book/10

40 Ayelén Fiebelkorn, "Faros en la ruta de la cultura: bibliotecas populares platenses, sus prácticas y encrucijadas (1936-1942)” La Plata, (2016). 
reutilizar esos contenidos ${ }^{41}$. Entre los resultados que deja su trabajo no solo se destaca esa apuesta metodológica - la de inscribir las operaciones culturales de la biblioteca de barrio en el abundante, exótico y heteróclito universo de la cultura de masas-, sino también una constatación fundamental: la ambivalente contradicción en la que se vieron envueltos aquellos fomentadores, entre la conservación de la lectura como eje vertebrador de la biblioteca y la incorporación de los nuevos productos culturales a la oferta de la institución. En la misma línea de trabajo, Ayelén Fiebelkorn pone su mirada sobre las bibliotecas populares de la ciudad de La Plata, en un proyecto todavía en curso, pero que, a diferencia de los estudios mencionados, promete indagar de modo exclusivo en las relaciones generadas entre estas instituciones y la transformación en las sociabilidades y los consumos culturales que supuso la sociedad de masas ${ }^{42}$. Una investigación así - como se aprecia en los citados trabajos de Sik-, representaría una avance para la historia de las bibliotecas como objeto de conocimiento, en tanto que dejarían de representar un capítulo dentro de una contexto heurístico distinto.

El grupo de indagaciones que se ocuparon de las relaciones entre sociabilidad, bibliotecas y cultura de masas durante el período de entreguerras tiene, en parte por el tipo de recorte metodológico utilizado, algunas deudas pendientes. Entre ellas, hay dos cuestiones primordiales: por una parte, la puesta en relación de las trasformación de las bibliotecas con los avatares del campo bibliotecario (en el sentido que Pierre Bourdieu le dio al término "campo"); por otra, la vinculación entre este conjunto de instituciones y el poder estructurante que el Estado ejerció a través de la Comisión Protectora, que no solo se erigió como una agencia administradora de recursos, sino que también produjo un discurso sobre la lectura, cuya recepción aún está por descubrirse. Esta segunda clave analítica puede apreciarse en las investigaciones realizadas sobre el tema durante el peronismo, énfasis que presumiblemente adquieren dada la preponderancia que la gestión justicialista puso en la administración del Estado como herramienta de redistribución de los recursos materiales y simbólicos.

${ }^{41}$ Diego Roldán, La invención de las masas: Ciudad, corporalidades y culturas. Rosario, 1910-1945 (La Plata: Universidad Nacional de La Plata. Facultad de Humanidades y Ciencias de la Educación, 2015)

${ }^{42}$ Ayelén Fiebelkorn, "Sociabilidades platenses en movimiento: bibliotecas populares frente al desafío de la cultura de masas", ponencia presenta en las VI Jornadas de Graduados e Investigadores en Formación (La Plata, 2016) 
Alvolver sobre la ciudad de Buenos Aires, Gutiérrez y Romero identificaron un estancamiento del activismo asociativo ${ }^{43}$, que también alcanzó a las bibliotecas populares. Las conjeturas planteadas por estos autores para justificar esa situación son diversas, aunque dos parecen ser las más gravitantes, por un lado, el viraje en el punto focal de la identificación de los sectores populares, que pasó del barrio al trabajo y de allí al sentimiento de pertenencia con el peronismo; por otro, el cumplimiento mismo de los objetivos institucionales, lo que indefectiblemente agotó las expectativas y las energías originales. Asimismo, trazaron sospechas entorno a la hostilidad de la conducción peronista hacia algunas asociaciones. No obstante, este elemento no explica por sí mismo el proceso decreciente que describen. En primer lugar, y como quedó dicho, las administraciones de la Comisión Protectora anteriores a este período no siempre fueron condescendientes con las organizaciones barriales. En segundo término, el asociacionismo se mantuvo vigoroso en otras regiones y ciudades, mientras que proliferó en las nuevas periferias metropolitanas. Finalmente, estudios recientes como los de Flavia Fiorucci demuestran que, durante los dos primeros mandatos peronistas (1946-1955), la Comisión Protectora no solo siguió la línea ideológica y pedagógica que había elaborado lenta pero paulatinamente desde su restitución en 1908 - incluso, las capas dirigentes de la entidad se mantuvieron con el cambio de gobierno de 1946-, sino que además amplió el presupuesto destinado a estas instituciones ${ }^{44}$. Por su parte, las indagaciones de Eugenia Costa, Marcela Coria y Paulo Renato Da Silva corroboran una atención gubernamental similar en el fomento de las bibliotecas populares en la provincia de Buenos Aires, por entonces atravesada bajo el mismo signo político ${ }^{45}$. Pero aun contando estos aportes,

${ }^{43}$ Leandro Gutiérrez y Luis Alberto Romero, Sectores populares, cultura y política: Buenos Aires en la entreguerra (Buenos Aires: Sudamericana, 1995).

${ }^{44}$ Flavia Fiorucci. "La cultura, el libro y la lectura bajo el peronismo: el caso de la Comisión de Bibliotecas Populares”. Desarrollo Económico, 48, n. ${ }^{\circ} 192$ (2009): 543-556.; Flavia Fiorucci. “El peronismo y el libro: la Revista de la Comisión de Bibliotecas Populares”. En: Ideas y debates para la Nueva Argentina. Revistas culturales y políticas del primer peronismo (1946-1955), editado por Claudi Panella y Guillermo Korn. t. 2, 149-166. (La Plata, Ediciones de Periodismo y Comunicación, 2014).

${ }^{45}$ María Eugenia Costa. "Formación bibliotecaria y difusión de la labor bibliográfica durante la gestión del ministro Avanza: el caso de la Revista Biblioteca”. En El gobierno de Domingo A. Mercante en Buenos Aires (1946-1952). Un caso de peronismo provincial, compilado por Claudio Panella. 176-190 (La Plata: Archivo Histórico de la Provincia de Buenos Aires “Dr. Ricardo Levene”, 2009); Marcela Coria. "La Escuela de Bibliotecología de la Provincia de Buenos Aires 
el conocimiento gestado con relación a este período y a estas agencias es muy escaso. En otro atractivo proyecto de investigación en curso, Coria promete un análisis de la Comisión Protectora entre los años 1933 y 1955, un examen que resultaría fundamental para comenzar a develar una parte medular de la historia bibliotecaria argentina ${ }^{46}$.

Con todo, y a partir de los indicios disponibles hasta el momento, el período de expansión o esplendor atribuido a las bibliotecas populares puede llevarse más allá del interregno clásico conformado por las dos guerras mundiales y fijarlo, de manera provisoria, en 1955. Esta fecha no solo podría justificarse en relación con el Golpe de Estado y el giro que tomaron las políticas estatales en adelante, sino también, y fundamentalmente, porque no se ha generado conocimiento sobre el devenir de las bibliotecas populares que permita elaborar un diagnóstico crítico desde 1955 a 1976. A partir de esta última fecha, y en la encrucijada formada por la historia y la memoria, las investigaciones de Natalia García y Florencia Bossie vuelven sobre la cuestión bibliotecaria en los difíciles y aciagos marcos represivos generados durante la última dictadura cívico-militar en la Argentina (1976-1983) ${ }^{47}$. Sus trabajos constituyen un punto de referencia para enlazar un pasado que aún está por descubrirse, y una sociología de las bibliotecas populares que todavía está pendiente.

y la profesionalización del bibliotecario (1948-1950)”. Palabra Clave (La Plata), vol. 4, n. ${ }^{\circ} 1$ (2014): 48-60; Marcela Coria. Libros, cultura y peronismo. La Dirección General de Bibliotecas de Buenos Aires [1946-1952] (La Plata: Archivo Histórico Dr. Ricardo Levene, 2017); Paulo Renato Da Silva. "Peronismo e cultura: o Primeiro Congresso de Bibliotecas Populares da Provincia de Buenos Aires (1949)”. Topoi, 11, n. ${ }^{\circ} 21$ (2010): 222-234.

${ }^{46}$ Marcela Coria, "Las políticas de lectura de la Comisión Nacional Protectora de la Bibliotecas Populares", ponencia presenta en las VI Jornadas de Graduados e Investigadores en Formación, (La Plata, 2016).

47 Florencia Bossie. "Recuerdos que resisten: Censuras, autocensuras y exilios en la ciudad de La Plata durante la última Dictadura Militar”. En: Biblioclastía: Los robos, la represión y sus resistencias en bibliotecas, archivos y museos de Latinoamérica, compilada por Tomás Solari y Jorge Gómez. 23-66. (Buenos Aires: Eudeba, 2008); Florencia Bossie. "Libros, bibliotecas y bibliotecarios: una cuestión de memoria”. Información, Cultura y Sociedad, n. 20 (2009): 3-40; Natalia García. “'Los contrabandistas de La Vigil”. En: Biblioclastía: Los robos, la represión y sus resistencias en bibliotecas, archivos y museos de Latinoamérica, compilada por Tomás Solari y Jorge Gómez. 245-275. (Buenos Aires: Eudeba, 2008); Natalia García. "Archivos y memorias. El caso "Vigil" y el corpus (re) aparecido", Corpus, archivos virtuales de la alteridad americana, 3, no. 2 (2013). 


\section{A modo de conclusión, una recapitulación interpretativa}

Al examinar los estudios existentes sobre la historia de las bibliotecas populares en Argentina surgen dos referencias claras. Una remite al siglo XIX, en especial a la figura política e intelectual de Domingo Faustino Sarmiento y, en menor medida, a la vida institucional de los establecimientos formados y dirigidos por distintas agrupaciones de la sociedad civil. La otra conduce a la primera mitad del siglo $\mathrm{xx}$, e incluye tanto a las asociaciones organizadas en los barrios metropolitanos y las ciudades intermedias del interior del país, como aquellas alentadas desde ámbitos externos a la comunidad vecinal, ya se trate del partido socialista, la liga patriótica o el propio Estado. Este conjunto bibliográfico es fragmentario. La mayoría de los artículos disponibles no tienen como foco de atención la historia de estas bibliotecas, sino que las conciben en el contexto de otros objetos de conocimientos de mayor tradición o envergadura historiográfica, como la cuestión de la sociabilidad o la constitución de las identidades populares. Sin embargo, en los últimos años pueden localizarse estudios concretos y proyectos en curso que tienen como objetivo la comprensión de este fenómeno sociocultural que cruzó, reunió y distanció a distintos sectores, entidades, ideologías e imaginarios, bajo la atracción poderosa de la biblioteca, en sus fases materiales y simbólicas.

Aun cuando la literatura analizada no conforma un corpus coherente, de sus desarrollos metodológicos, perspectivas teóricas y constataciones pueden extraerse algunos elementos que harían posible un proyecto heurístico amplio. En este sentido, y al recuperar y tamizar algunas de esas enseñanzas, resulta imprescindible restituir tres dimensiones analíticas del concepto "biblioteca popular”. En primer término, entonces, debe comprenderse esta noción como la manifestación de una articulación entre el poder estructurante del Estado y el espacio creativo de la sociedad civil. Esta fase involucra el análisis de las formaciones discursivas, las estrategias que desplegaron los funcionarios a cargo de interpretar y administrar el sistema y, por último, las habilidades que utilizaron las asociaciones para sacar el mejor rédito de las disposiciones establecidas. La relación entre lo estatal y lo social asociativo tuvo diferentes niveles de vinculación a lo largo del tiempo: acuerdos fructíferos, tensiones con resultados dispares, vigilancia gubernamental de variable intensidad según el cariz democrático, autoritario o abiertamente totalitario del partido o coalición de gobierno - e indiferencia mutua. Pero aun cuando el Estado desdeñó completamente la atención de las bibliotecas populares entre sus políticas de la lectura - o ignoró a muchas de ellas por motivos ideológicos, 
partidarios o de otro tipo-, su presencia o ausencia constituye un factor clave para comprender globalmente esta historia.

Plantear el concepto biblioteca popular remite a un segundo elemento, que puede identificarse con las ideas y las personalidades de diferentes niveles que hicieron posible su diseño intelectual. Sarmiento es emblemático y, por lo mismo, útil para ejemplificar esta dimensión. Sus intervenciones pueden disponerse en tres planos: de un lado, en su coherencia interna y en el sistema de vinculaciones que mantuvo con otras producciones discursivas pretéritas y contemporáneas a las suyas; de otro, en relación sincrónica con las apropiaciones que hicieron de sus textos, tanto por parte de aquellos que se encargaron de administrar desde el Estado una política de la lectura (entendida en términos materiales y simbólicos), como de esos otros lectores anónimos que se ocuparon de resignificar y hacer práctico ese saber mediante la organización de una biblioteca popular. Finalmente, una dimensión diacrónica, imprescindible para restituir el juego de apropiaciones que se hicieron de sus ideas en el tiempo, en figuras públicas como Ángel Giménez o Juan Pablo Echagüe, o en personajes menos visibles - como se descubre, por ejemplo, al leer las notas de opinión que relevó Sik en La Protesta, donde las críticas que recaían sobre Paul Groussac por el rumbo de la Biblioteca Nacional eran expuestas en los mismo términos en los que Sarmiento había atacado décadas atrás a Vicente Quesada, cuando este administraba la Biblioteca Pública de Buenos Aires, nacionalizada con posterioridad-. De la extensión de este esquema metodológico hacia otros autores más o menos encumbrados depende, en gran medida, la restitución de los discursos sobre las bibliotecas populares y sus reutilizaciones en las bibliotecas, ya sea para delinear el espíritu de las entidades, definir los lineamientos de lectura u organizar el material bibliográfico y establecer las pautas de uso.

Por último, la noción de biblioteca popular requiere pensar en un lugar practicado por lectores y bibliotecarios. Se trata de extender un análisis sobre los modos en que estos actores, inscriptos en sistemas peculiares de sociabilidad, le dieron sentido a las instituciones a través de sus decisiones, rituales, tiempos, costumbres, criterios y reglas. Este principio exige una distinción básica entre los lectores que tomaron el compromiso de conducir los destinos institucionales y aquellos que, en general, pueden considerarse como público. Esta divergencia resulta clave para comprender la construcción misma del dispositivo biblioteca, cuya especificidad hay que buscarla, inicialmente, 
en tres módulos: la disposición del lugar y su mantenimiento, la selección de las obras y la circulación social de la lectura.

En primer término, una biblioteca remite a una espacialidad, aunque con diferentes marcos de estabilidad temporal. Por lo tanto, el ambiente sobre el cual se construye condensa objetos y rutinas que la ordenan y estructuran el hacer de quienes la transitan. La infraestructura y el mobiliario, así como también las tareas que definen sus usos, no solo hacen posible la conversión material de una habitación cualquiera en un recinto de lectura, también se expresan como variación simbólica de los sentidos estéticos que le atribuyeron a estos establecimientos quienes se ocuparon de su gestión. Esta construcción contribuye a fijar los vínculos entre la biblioteca y un público. El segundo elemento analítico de este eje puede formularse mediante una pregunta básica, esencial: ¿qué y cómo fueron seleccionadas las obras que integraron las colecciones? Para obtener algunas respuestas, cabría replegarse sobre el juego de inquietudes que se verifican entre el nivel individual, donde cada lector se ve obligado a procesar un juicio con lo que tiene de capital cultural, lo que desea y la demostración de cierta legitimidad ante los demás, y la fase grupal, en la que se extiende la necesidad de conciliar las posiciones que los asociados manifiestan con relación al mercado de valoraciones literarias, políticas, morales y filosóficas. La resultante expone un modo singular de ver el mundo de la lectura e intervenir en él. Como sucede con la construcción del espacio, la cristalización de un catálogo participa en la definición de los vínculos entre la biblioteca y la comunidad de lectores. Estos dos primeros aspectos constituyen el tercer módulo en cuestión, esto es, las estructuras elementales de la circulación social de la lectura y, más allá de ella, de la selección y la amplificación de los mensajes culturales que circularon en cada época, mediante la forma y el sentido que profiere el libro o a través de la incorporación de contenidos audiovisuales, como la asimilación del cine a la cartera de actividades. Sea que esta circulación remita a instancias individuales de apropiación - como sucede, en efecto, con el préstamo domiciliario de las obras o con la lectura en las salas silenciosas - o a la multiplicación de los encuentros donde se construyen procesos interpretativos colectivos - típico de las veladas literarias o de las proyecciones cinematográficas-, la biblioteca funge como un pivote que asocia de forma tangible una propuesta cultural con un lectorado singular.

Estos puntos de partida no invalidan la incorporación de tópicos que, por lo demás, necesitan una comprensión de larga duración - como el espacio de 
vacancia formado por el cruce entre problemáticas de género y bibliotecas-. No obstante, ese inicio puede contribuir a subsanar los olvidos que aún mantienen los estudios históricos sobre las bibliotecas populares en la Argentina, que como se podrá percibir, no solo se refieren a los avatares de unas instituciones de otros tiempos, sino a una indagación de carácter social, cultural y antropológica, de cuyos resultados depende la formación de un pensamiento histórico para el campo que no es pura historia, sino un modo crítico de pensar.

\section{Referencias bibliográficas}

\section{Fuentes secundarias}

Barrancos, Dora. "Socialistas y la suplementación de la escuela pública: la Asociación de Bibliotecas y Recreos infantiles (1913-1930)”. En: Mujeres en la Educación. Género y docencia en la Argentina: 1870-1930, editado por Graciela Morgade. Buenos Aires: Miño Dávila, 1997, 130-150.

Barrancos, Dora. Educación, cultura y trabajadores (1890-1930). Buenos Aires: Centro Editor de América Latina, 1991.

Batticuore, Graciela. "Libros, Bibliotecas y lectores en las encrucijadas del progreso". En: Historia Crítica de la Literatura Argentina: el brote de los géneros, dirigido por Alejandra Laera. 413-440. Buenos Aires: EMECÉ, 2010.

Batticuore, Graciela. La mujer romántica: lectoras, autoras y escritores en la Argentina: 1830-1870. Buenos Aires: Edhasa, 2005.

Bossie, Florencia. "Libros, bibliotecas y bibliotecarios: una cuestión de memoria". Información, Cultura y Sociedad, n. 20 (2009): 3-40.

Bossie, Florencia. "Recuerdos que resisten: Censuras, autocensuras y exilios en la ciudad de La Plata durante la última Dictadura Militar". En: Biblioclastía: Los robos, la represión y sus resistencias en bibliotecas, archivos y museos de Latinoamérica, compilada por Tomás Solari y Jorge Gómez. 23-66. Buenos Aires: Eudeba, 2008.

Buonocore, Domingo. Libreros, editores e impresores de Buenos Aires: esbozo para una historia del libro argentino. Buenos Aires: Bowker, 1974.

Camarero, Hernán. A la conquista de la clase obrera: los comunistas y el mundo del trabajo en la Argentina, 1920-1935. Buenos Aires: Siglo XXI, 2007.

Carli, Sandra. "Infancia y sociedad: la mediación de las asociaciones, centros y sociedades populares de educación". En Sociedad Civil y Estado en los orígenes del sistema educativo argentino, dirigida por Adriana Puiggros. 13-46. Buenos Aires: Galerna, 1991,

Chartier, Roger y Guglielmo Cavallo (dirs.). Historia de la lectura en el mundo occidental. Buenos Aires: Taurus, 1997.

Chartier, Roger. Cardenio entre Cervantes y Shakespeare. Historia de una obra perdida. Buenos Aires: Gedisa, 2012.

Chartier, Roger. El mundo como representación: estudios sobre historia cultural. Barcelona: Gedisa, 1992. 
Chartier, Roger. Escribir las prácticas: Foucault, de Certeau, Marin. Buenos Aires: Manantial, 1996.

Chartier, Roger. Escuchar a los muertos con los ojos. Lección inaugural en el Collège de France. Buenos Aires: Katz, 2008.

Chartier, Roger. Libros, lecturas y lectores en la Edad Moderna. Madrid: Alianza, 1993.

Chartier, Roger. Sociedad y escritura en la Edad Moderna. La cultura como apropiación. México: Instituto Mora, 1995.

Comisión Protectora de Bibliotecas Populares. Paginas selectas de Sarmiento sobre bibliotecas populares. Buenos Aires: la Comisión, 1940.

Corbiére, Emilio J. "La cultura Obrera Argentina como base de transformación social (1890-1940)”. Herramienta: debate y crítica marxista, n. ${ }^{\circ} 12$ (2000). https:// herramienta.com.ar/articulo.php?id=854

Coria, Marcela. "La Escuela de Bibliotecología de la Provincia de Buenos Aires y la profesionalización del bibliotecario (1948-1950)”. Palabra Clave (La Plata), vol. 4, n. ${ }^{\circ} 1$ (2014): 48-60 http://www.palabraclave.fahce.unlp.edu.ar/article/view/ PCV4n1a04

Coria, Marcela. "Las políticas de lectura de la Comisión Nacional Protectora de la Bibliotecas Populares”, ponencia presentada en las VI Jornadas de Graduados e Investigadores en Formación. La Plata, 2016.

Coria, Marcela. Libros, cultura y peronismo. La Dirección General de Bibliotecas de Buenos Aires [1946-1952]. La Plata: Archivo Histórico Dr. Ricardo Levene, 2017.

Costa, María Eugenia. "Formación bibliotecaria y difusión de la labor bibliográfica durante la gestión del ministro Avanza: el caso de la Revista Biblioteca”. En El gobierno de Domingo A. Mercante en Buenos Aires (1946-1952). Un caso de peronismo provincial, compilado por Claudio Panella. 176-190. La Plata: Archivo Histórico de la Provincia de Buenos Aires “Dr. Ricardo Levene”, 2009.

Da Silva, Paulo Renato. "Peronismo e cultura: o Primeiro Congresso de Bibliotecas Populares da Provincia de Buenos Aires (1949)”. Topoi, 11, n. ${ }^{\circ} 21$ (2010): 222-234.

Darnton, Robert. "Historia de la Lectura”. En: Formas de hacer historia, dirigido por Peter Burke, 177-208. Madrid: Alianza, 1993.

Darnton, Robert. Edición y subversión: literatura clandestina en el Antiguo Régimen. Madrid-México: Turner; Fondo de Cultura Económica, 2003.

Darnton, Robert. El beso de Lamourette: reflexiones sobre historia cultural. Buenos Aires: Fondo de Cultura Económica, 2010.

Darnton, Robert. Elnegocio de la Ilustración. Historia editorial de la Encyclopédie, 17751800. México: Fondo de Cultura Económica, 2006.

Darnton, Robert. La gran matanza de gatos y otros episodios de la cultura francesa. México: Fondo de Cultura Económica, 1987

Darnton, Robert. Los best sellers prohibidos en Francia antes de la Revolución. México: Fondo de Cultura Económica, 2008.

De Miguel, Adriana et. ál. "Normalismo, cultura letrada y resistencia de la oralidad en la historia de la lectura y la escritura en Argentina”. Ciencia, docencia y tecnología, n. ${ }^{\circ} 34$ (2007): 97-127. http://www.scielo.org.ar/pdf/cdyt/n34/n34a04.pdf 
De Miguel, Adriana. "Escenas de lectura escolar. La intervención normalista en la formación de la cultura letrada moderna”. En Historia de la lectura en la Argentina. Del catecismo colonial a las netbooks estatales. Héctor Rubén Cucuzza y Roberta Paula Spregelburd. 133-169. Buenos Aires: Editoras del Calderón, 2012.

Di Stefano, Mariana. El lector libertario: prácticas e ideologías del anarquismo argéentino (1898-1915). Buenos Aires: Eudeba, 2013.

Dolabani, Milagros. "La Biblioteca Popular Juventud Moderna: teatro, política, sociabilidad y esparcimiento (1939-1947)", ponencia presentada en el I Congreso Internacional de Investigadorxs sobre Anarquismo. Buenos Aires, 2016.

Echagüe, Juan Pablo. Libros y bibliotecas. Buenos Aires: Comisión Protectora de Bibliotecas Populares, 1939.

Fiebelkorn, Ayelén. "Faros en la ruta de la cultura: bibliotecas populares platenses, sus prácticas y encrucijadas (1936-1942)”. La Plata, 2016.

Fiebelkorn, Ayelén. "Sociabilidades platenses en movimiento: bibliotecas populares frente al desafío de la cultura de masas", ponencia presenta en las VI Jornadas de Graduados e Investigadores en Formación. La Plata, 2016b.

Fiorucci, Flavia. "El peronismo y el libro: la Revista de la Comisión de Bibliotecas Populares”. En: Ideas y debates para la Nueva Argentina. Revistas culturales y politicas del primer peronismo (1946-1955), editado por Claudi Panella y Guillermo Korn. t. 2, 149-166. La Plata, Ediciones de Periodismo y Comunicación, 2014.

Fiorucci, Flavia. "La cultura, el libro y la lectura bajo el peronismo: el caso de la Comisión de Bibliotecas Populares”. Desarrollo Económico, 48, n. ${ }^{\circ} 192$ (2009): 543-556.

Furlong, Guillermo. Bibliotecas argentinas durante la dominación hispánica. Buenos Aires: Huarpes, 1944.

García, Natalia. "Archivos y memorias. El caso "Vigil” y el corpus (re) aparecido". Corpus, archivosvirtuales de la alteridad americana, 3, n. 2 (2013). http://ri.conicet. gov.ar/handle/11336/15575

García, Natalia. (2008). "Los contrabandistas de La Vigil”. En: Biblioclastía: Los robos, la represión y sus resistencias en bibliotecas, archivos y museos de Latinoamérica, compilada por Tomás Solari y Jorge Gómez. 245-275. Buenos Aires: Eudeba, 2008.

Giménez, Ángel M. Nuestras Bibliotecas Obreras. Buenos Aires: La Vanguardia, 1932. González, Ricardo. "Lo propio y lo ajeno: Actividades culturales y fomentismo en una asociación vecinal, Barrio Nazca (1925-1930)”. En Mundo urbano y cultura popular. Estudios de Historia Social Argentina, compilada por Diego Armus. 91-128 Buenos Aires: Sudamericana, 1990.

Gutiérrez, Leandro y Luis Alberto Romero. Sectores populares, cultura y política: Buenos Aires en la entreguerra. Buenos Aires: Sudamericana, 1995.

Horowitz, Joel. "Finding a Place to Read: Popular Libraries in Greater Buenos Aires before 1945", ponencia presentada en el Seminario de discusión del Programa de Estudios sobre Saberes de Estado y Elites Estatales. Buenos Aires, 2016.

Lucero, Amador. Nuestras bibliotecas desde 1810. Buenos Aires: Coni, 1910.

Lugones, Leopoldo. Historia de Sarmiento. Buenos Aires: Otero \& Compañía, 1911. 
Parada, Alejandro E. El Dédalo y su ovillo. Ensayos sobre la palpitante cultura impresa en la Argentina. Buenos Aires: Instituto de Investigaciones Bibliotecológicas, Facultad de Filosofía y Letras, Universidad de Buenos Aires, 2012.

Parada, Alejandro E. Los orígenes de la Biblioteca Pública de Buenos Aires: antecedentes, prácticas, gestión y pensamiento bibliotecario durante la revolución de mayo. Buenos Aires: Instituto de Investigaciones Bibliotecológicas, Facultad de Filosofía y Letras, Universidad de Buenos Aires, 2009.

Pasolini, Ricardo. “Entre la evasión y el humanismo. Lecturas, lectores y cultura de los sectores populares: La Biblioteca Juan B. Justo de Tandil, 1928-1945”. Anuario IEHS, n. ${ }^{\circ} 12$ (1997): 373-401.

Perrot-Desseaux, Charlotte. «Les bibliothèques populaires argentines, ou quand la promotion de la lecture est prise en charge par la "communauté"». En: Des bibliothèques populaires à la lecture publique, dirigido por d'Agnès Sandras. 373-394. Villeurbanne: Presses de l'Enssib, 2014.

Planas, Javier. "Hacer las reglas del hacer: concepciones y rutinas en los reglamentos de las bibliotecas populares en la Argentina (1870-1875)". Revista de Historia Regional, 19, n.. 1 (2014a): 203-226. http://www.revistas2.uepg.br/index.php/ rhr/article/viewFile/6117/4095

Planas, Javier. "La esencia de una biblioteca popular. Una polémica sobre los lectores y las modalidades de acceso a la lectura", ponencia presentada en las Segundas Jornadas de Intercambio y Reflexión acerca de la Investigación Bibliotecología. La Plata, 2011. http://jornadabibliotecologia.fahce.unlp.edu.ar/jornadas2011/actas-2011/ planas-la-esencia

Planas, Javier. "Las bibliotecas populares en la Argentina entre 1870 y 1875 . La construcción de una política bibliotecaria”. Informatio, 18, n. . 1, (2014b): 66-88 http://informatio.eubca.edu.uy/ojs/index.php/Infor/article/view/152/229

Planas, Javier. "Lectoras, autoras y bibliotecarias: presencias y ausencias de las mujeres en las bibliotecas populares de la Argentina (1870-1890)", ponencia presentada en las Terceras Jornadas de Intercambio y Reflexión acerca de la Investigación Bibliotecología, La Plata, 2013 http://jornadabibliotecologia.fahce.unlp.edu.ar/ jornadas-2013/actas-2013/planas.pdf/view

Planas, Javier. "Lugares y espacios para la literatura en la Argentina del XIX. Las bibliotecas populares en los circuitos de la lectura" En Tropos, tópicos y cartografias: figuras del espacio en la literatura latinoamericana, editado por Carolina Sancholuz y Valeria Añón. La Plata: Facultad de Humanidades y Ciencias de La Educación, 2017. www.libros.fahce.unlp.edu.ar/index.php/libros/catalog/view/89/110/810-1

Planas, Javier. "Para un catálogo atractivo: libros y política editoriales para las bibliotecas populares. La propuesta de Domingo Faustino Sarmiento". Información, Cultura y Sociedad, n. 20 (2009): 63-81.

Planas, Javier. “¿Cuáles serán los libros buenos?” Tensiones culturales y políticas de lectura en los orígenes de las bibliotecas populares en Argentina", ponencia presentada en el II Coloquio Argentino de Estudios sobre el Libro y la Edición, Córdoba, 2016 
Planas, Javier. Libros, lectores y sociabilidades de lectura. Una historia de los orígenes de las bibliotecas populares en Argentina. Buenos Aires: Ampersand, 2017.

Poblete, Juan. Literatura chilena del siglo XIX: entre públicos lectores y figuras autoriales. Santiago: Cuarto Propio, 2003.

Poy, Lucas. "Socialismo y anarquismo en la formación de la clase obrera en Argentina: problemas historiográficos y apuntes metodológicos". Archivos de historia del movimiento obrero y la izquierda, n. ${ }^{\circ}$ 1, (2012): 3-34.

Prieto, Adolfo. "Sarmiento: casting the readers, 1839-1845". En Sarmiento: author of a nation, Tulio Halperin Donghi et. ál.259-271. Berkeley: University of California Press, 1994.

Prieto, Adolfo. El discurso criollista en la formación de la Argentina moderna. Buenos Aires: Siglo XXI, 1988.

Prieto, Adolfo. Sociología del público lector. Buenos Aires: Leviatán, 1956.

Quiroga, Nicolás. "Lectura y política. Los lectores de la biblioteca popular juventud moderada de Mar del Plata (fines de los años treinta y principio de los cuarenta)". Anuario IEHS, n. 18 (2003): 449-474.

Roldán, Diego. La invención de las masas: ciudad, corporalidades y culturas. Rosario, 1910-1945. La Plata: Universidad Nacional de La Plata. Facultad de Humanidades y Ciencias de la Educación, 2015. http://www.libros.fahce.unlp.edu.ar/index.php/ libros/catalog/book/10

Romero, Luis Alberto. El Estado y las Corporaciones. En De las cofradías a las organizaciones de la sociedad civil: historia de la iniciativa asociativa en la argentina (17761990), Roberto di Stefano et. ál. Buenos Aires: Edibal, 2002. p. 169-275.

Sabor Riera, María Ángeles. Contribución al estudio histórico del desarrollo de los servicios bibliotecarios de la Argentina en el siglo XIX. Resistencia: Universidad Nacional del Nordeste, Dirección de Bibliotecas, 1974-1975.

Sarlo, Beatriz. "Raymond Williams y Richard Hoggart: sobre cultura y sociedad". Punto de Vista, 2, n. 6 (1979): 9-18.

Sarlo, Beatriz. El imperio de los sentimientos. Narraciones de circulación periódica en la Argentina (1917-1927). Buenos Aires: Catálogos, 1985.

Sarmiento, Nicanor. Historia del libro y de las bibliotecas en la Argentina. Buenos Aires: Imprenta Luis Veggia, 1930.

Sik, Eugenia. "Ángel M. Giménez, "bibliotecarios”. Apunte para una historia de las "bibliotecas obreras" en Argentina”, ponencia presentada en el II Coloquio Argentino de Estudios sobre el Libro y la Edición, Córdoba, 2016.

Sik, Eugenia. La creación de bibliotecas durante el apogeo del anarquismo argentino (1898-1905”), ponencia presentada en el I Congreso Internacional de Investigadorxs sobre Anarquismo, Buenos Aires, 2016.

Subercaseaux, Bernardo. Historia del libro en Chile (alma y cuerpo). Santiago de Chile: LOM, 2000.

Suriano, Juan. Anarquistas: cultura política y libertaria, 1890-1910. Buenos Aires: Manantial, 2008. 
Tarcus, Horacio. Marx en la Argentina. Sus primeros lectores obreros, intelectuales y científicos. Buenos Aires: Siglo XXI, 2007.

Tasso, Alberto. "La biblioteca Sarmiento de Santiago del Estero (1880-1915). Socorros mutuos, libros y lectores”. Políticas de la Memoria, n. 14 (2013): 105-109.

Torre Revello, José. Orígenes de la imprenta en España y su desarrollo en América española. Buenos Aires: Institución Cultural Española, 1940.

Tripaldi, Nicolás. "Indicadores de crisis: el caso de las bibliotecas populares argentinas", Ponencia presentada en la XXV Reunión Nacional de Bibliotecarios: la biblioteca y los bibliotecarios en tiempos de crisis, Buenos Aires, 1991.

Tripaldi, Nicolás. "La política y los centros de lectura: los socialistas fundan sus primeras bibliotecas en la ciudad de Buenos Aires 1894-1899”. Revista de Biblioteconomía de Brasilia, 20, n. 1 (1996): 41-51.

Tripaldi, Nicolás. "Las mujeres de la política, los niños de la calle y las bibliotecas: apostillas bibliotecológicas sobre el tema de la Asociación de Bibliotecas y Recreos Infantiles”. Información, Cultura y Sociedad, n. 7 (2002): 81-101.

Tripaldi, Nicolás. "Origen e inserción de las bibliotecas obreras en el entorno bibliotecario argentino: fines del siglo XIX y primer tercio del siglo XX”. Libraria: Correo de las Bibliotecas, 1, n. ${ }^{\mathrm{o}} 1$ (1997): 22-37.

Vignoli, Marcela. "Asociacionismo, cultura y política en tiempos de crisis, la Sociedad Sarmiento de Tucumán, 1900-1909”. Travesías, n. ${ }^{\circ} 12$ (2010): 187-214. http:// www.travesia-unt.org.ar/pdf/travesia12_8.pdf

Vignoli, Marcela. "Educadoras, lectoras y socias. La irrupción de las mujeres en un espacio de sociabilidad masculino. La Sociedad Sarmiento de Tucumán (Argentina) entre 1882 y 1902”. Secuencia, n. ${ }^{\circ}$ 80, (2011): 43-62. http://www.scielo.org. $\mathrm{mx} / \mathrm{pdf} / \mathrm{secu} / \mathrm{n} 80 / \mathrm{n} 80 \mathrm{a} 2 . \mathrm{pdf}$

Vignoli, Marcela. Sociabilidad y cultura política. La sociedad Sarmiento de Tucumán (1880-1914). Rosario: Prohistoria, 2015. 